\title{
Public preferences for vaccination programmes during pandemics caused by pathogens transmitted through respiratory droplets - a discrete choice experiment in four European countries, 2013
} \author{
Bekker-Grob ${ }^{1}$ \\ 1. Erasmus MC, University Medical Center Rotterdam, Rotterdam, the Netherlands \\ 2. National Institute for Public Health and the Environment (RIVM), Bilthoven, the Netherlands \\ 3. University of Michigan, Ann Arbor, Michigan, United States \\ 4. VA Ann Arbor Center for Clinical Management Research, Ann Arbor, Michigan, United States \\ 5. The University of Sydney Business School, Sydney, New South Wales, Australia \\ 6. Rotterdam-Rijnmond Municipal Public Health Service, Rotterdam, the Netherlands
}

D Determann ${ }^{12}$, IJ Korfage ${ }^{1}$, A Fagerlin ${ }^{34}$, EW Steyerberg ${ }^{1}$, MC Bliemer ${ }^{5}$, HA Voeten ${ }^{6}$, JH Richardus ${ }^{16}$, MS Lambooij ${ }^{2}$, EW de

Correspondence: Esther W de Bekker-Grob (e.debekker@erasmusmc.nl)

This study aims to quantify and compare preferences of citizens from different European countries for vaccination programme characteristics during pandemics, caused by pathogens which are transmitted through respiratory droplets. Internet panel members, nationally representative based on age, sex, educational level and region, of four European Union Member States (Netherlands, Poland, Spain, and Sweden, $n=2,068$ ) completed an online discrete choice experiment. These countries, from different geographical areas of Europe, were chosen because of the availability of high-quality Internet panels and because of the cooperation between members of the project entitled Effective Communication in Outbreak Management: development of an evidence-based tool for Europe (ECOM). Data were analysed using panel latent class regression models. In the case of a severe pandemic scenario, vaccine effectiveness was the most important characteristic determining vaccination preference in all countries, followed by the body that advises on vaccination. In Sweden, the advice of family and/or friends and the advice of physicians strongly affected vaccine preferences, in contrast to Poland and Spain, where the advice of (international) health authorities was more decisive. Irrespective of pandemic scenario or vaccination programme characteristics, the predicted vaccination uptakes were lowest in Sweden, and highest in Poland. To increase vaccination uptake during future pandemics, the responsible authorities should align with other important stakeholders in the country and communicate in a coordinated manner.

\section{Introduction}

In the past 100 years, there have been several largescale influenza outbreaks with worldwide impact. These include the 1918 influenza $A\left(\mathrm{H}_{1} \mathrm{~N}_{1}\right)$ pandemic that caused between 50 and 100 million deaths particularly in many healthy young adults [1], and more recently the 2009 influenza $A\left(\mathrm{H}_{1} \mathrm{~N}_{1}\right)$ pdmog pandemic [2]. Though characteristics (such as clinical attack rates and pathogenicity) and occurrence of a next influenza pandemic are unpredictable, experts agree there will be future influenza pandemics [2-5].

The World Health Organisation (WHO) urged countries to develop or update national influenza preparedness plans in response to the avian influenza $A\left(\mathrm{H}_{5} \mathrm{~N}_{1}\right)$ pandemic threat in 2005 [6]. Such plans subsequently needed to be improved taking into account the lessons learnt from the response to the influenza $A\left(\mathrm{H}_{1} \mathrm{~N}_{1}\right)$ pdmog pandemic $[4,7,8]$. In addition, countries could learn from each other by sharing information and best practices [9].

Preventive measures are very important in limiting the spread of an influenza pandemic [10-12] and if available, vaccination constitutes the control cornerstone $[13,14]$. The success of mitigating influenza pandemics depends on many factors, including national public health policies and the availability of vaccines, vaccine effectiveness, and the public's willingness to get vaccinated. Unfortunately, vaccination coverage has proven to be (too) low across Europe during the influenza $\mathrm{A}\left(\mathrm{H}_{1} \mathrm{~N}_{1}\right)$ pdmog pandemic. Vaccination coverage among the general public of the European Union, Norway and 


\section{FIGURE 1}

Response to the survey to investigate public preferences for vaccination programmes during pandemics caused by pathogens transmitted through respiratory droplets, Netherlands, Poland, Spain, and Sweden, 2013
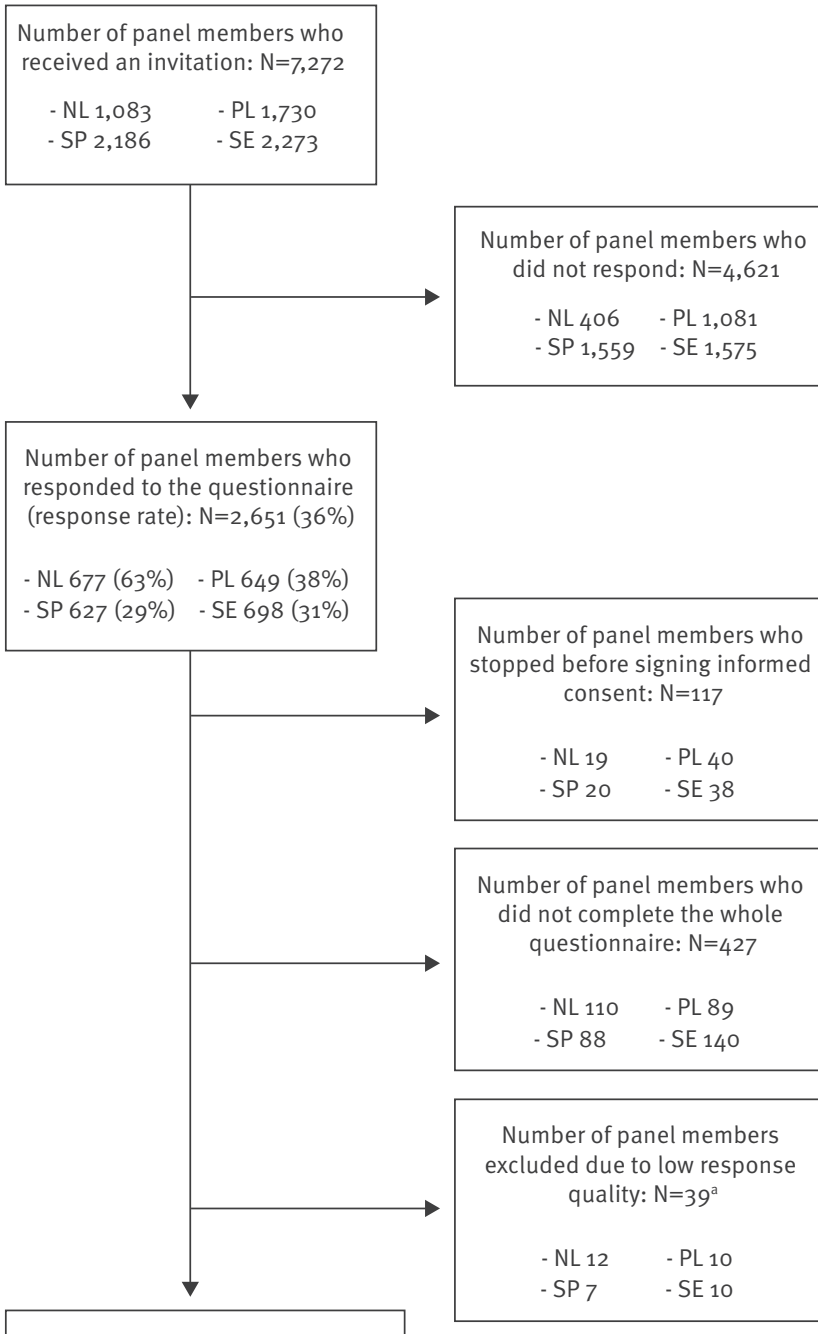

Number of panel members included

in the analysis (completion rate) $\mathrm{N}=2,068(78 \%)$

NL $536(79 \%)$ - PL $510(79 \%)$

SP $512(82 \%) \quad-$ SE $510(73 \%)$

NL: Netherlands; PL: Poland; SE: Sweden; SP: Spain.

${ }^{a}$ Low response quality was defined as completing the survey in less than $4 \mathrm{~min}$.

Iceland, varied between countries from $0.4 \%$ to $59 \%$ [15].

Countries within Europe differ from each other with regard to languages, cultures, public trust in health authorities, health system infrastructures, and public health capabilities and capacities. Research has shown that implementing international guidelines at the local level can be a complex process [16]. Having insights into country-specific reasons to accept or decline pandemic influenza vaccination can facilitate the adaptation of preparedness plans, including vaccination strategies, to the local situation [17].

Thus far, only a limited number of reports have focused on the comparison of pandemic influenza vaccination preferences between people of different European countries $[18,19]$, and formal quantitative techniques such as discrete choice experiments (DCEs) $[20,21]$ have not yet been used. The primary aim of this study was to quantify and compare the preferences of European citizens for vaccination programmes for future pandemics. Although we focus on influenza pandemics, we quantified vaccination programme preferences for any emerging or re-emerging large-scale infectious disease outbreak that spreads through respiratory droplets. Our findings might therefore also be applicable to other respiratory infections than influenza, such as, for example, severe acute respiratory syndrome (SARS)-coronavirus (CoV) or Middle East Respiratory Syndrome (MERS)-CoV, should vaccines be available for these viruses in the future. A secondary aim was to calculate the expected uptake of vaccination under different pandemic scenarios. The approach and results might help health policymakers to improve pandemic preparedness plans and communication strategies, in order to make future vaccination programmes more successful.

\section{Methods}

\section{Study population}

We surveyed a representative sample of the general public (age 18 years and over) of countries from different parts of Europe: eastern Europe (Poland), northern Europe (Sweden), southern Europe (Spain) and western Europe (Netherlands). These countries were chosen because of the availability of high-quality Internet panels (i.e. panels that are ISO certified and/or follow international quality standards for market research) and also because of the cooperation between project members of different work packages within the Effective Communication in Outbreak Management: development of an evidence-based tool for Europe (ECOM) project (www.ecomeu.info). The public health policies of the four included countries with respect to seasonal influenza and influenza $A\left(\mathrm{H}_{1} \mathrm{~N}_{1}\right)$ pdmog are described in Table 1.

\section{Discrete choice experiments}

A DCE is a survey-based stated-preference methodology that originates in mathematical psychology [22]. The method has been increasingly used in healthcare, whereby the number of published DCEs has increased from a mean of three per year in the period from 1990 to 2000 to 45 per year between 2009 and 2012 [23]. In a DCE, the relative importance of characteristics (i.e. attributes) of a certain product or intervention is assessed by presenting a series of choice sets to respondents $[20,21]$. In each choice set, respondents are asked to choose a preferred alternative from a set 
Relative importance of vaccination programme attributes for respondents' decision to get vaccinated in the case of mild and severe pandemic scenarios caused by pathogens transmitted through respiratory droplets, Netherlands, Poland, Spain, and Sweden, $2013(\mathrm{n}=2,068)$

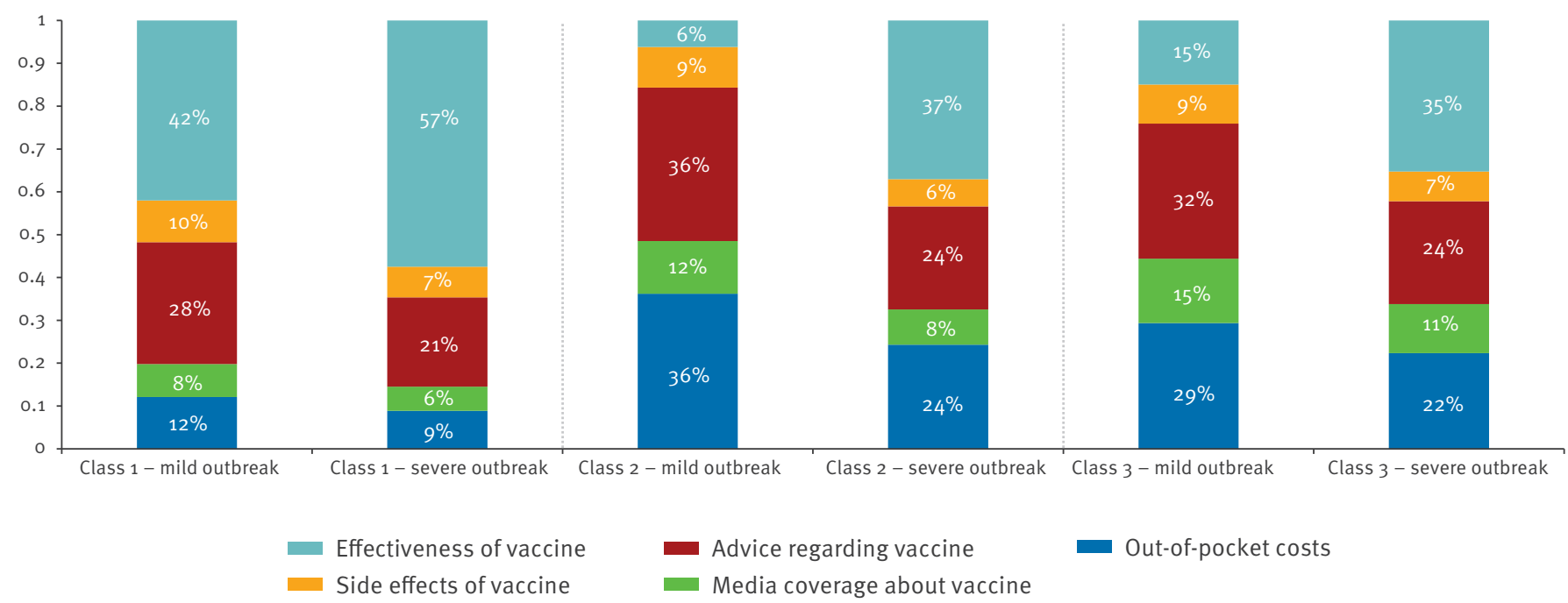

The percentages represent the proportion of someone's preference that is based on that attribute (utility). A mild pandemic was defined as a pandemic in which $5 \%$ of the population gets the disease (pandemic scenario variable susceptibility), and $5 \%$ of the sick people developing severe symptoms (pandemic scenario variable severity). A severe pandemic was defined as a pandemic in which $20 \%$ of the population gets the disease (pandemic scenario variable susceptibility), and $75 \%$ of the sick people develop severe symptoms scenario variable (pandemic scenario variable severity).

of two or more hypothetical product or intervention alternatives with systematically varying attribute levels $[20,21]$.

\section{Survey}

The survey started with an explanation of the DCE exercise. Next, respondents were asked to imagine that a large-scale emerging infectious disease, that started abroad, had spread to the country they lived in. It was stated that the disease spreads through respiratory droplets, that it was vaccine-preventable, and that vaccines were available in their country. Respondents then completed a series of choice sets, followed by questions about socio-demographic characteristics (including previous vaccination experiences), and questions that assessed the perceived difficulty of the survey. The survey ended with an open question in which respondents were given the opportunity to comment on the survey.

In each choice set, a hypothetical pandemic scenario based on two disease variables (susceptibility to the disease (i.e. a number of 1,000 people will get sick) and severity of the disease (i.e. a number of the sick people will develop severe symptoms) was presented. Respondents were then asked to choose between three alternatives: no vaccination, vaccination $A$, and vaccination $B$. The vaccination was described by several attributes, and the presented levels differed systematically between vaccination $A$ and vaccination $B$. In the following choice sets, both the pandemic scenario and the presented attribute levels for vaccination
A and B differed. In order to select realistic, relevant and understandable attributes and attributes levels, we conducted a literature study, expert interviews, and focus group discussions. In addition, we closely cooperated with project members when selecting the attributes and levels. PubMed, Embase and Psychinfo were strategically searched for relevant research articles on vaccination preferences. Expert interviews $(n=9)$ were conducted with both national and international experts (physicians, researchers, policymakers) in the field of infectious diseases, vaccinations, preventive behaviour, and implementation of prevention. We conducted eight focus group discussions with representatives of the general population, of which four in the Netherlands, two in Poland, two with Spanish citizens during their temporary stay in the Netherlands, and two in Sweden. Eligible participants were recruited by research companies and via our network, using purposive sampling to ensure a diverse sample. The focus groups revealed that similar vaccination programme attributes and attribute levels could be included in the DCE for all countries (Table 2). It is not feasible to present a single respondent with all the possible combinations of the included attribute levels. We therefore generated a subset of 48 choice sets by minimizing the D-efficiency criterion using the software programme Ngene (ChoiceMetrics, version 1.1.1). The 48 choice sets were grouped in three different survey versions such that each block has (near) attribute level balance. Each respondent thus needed to answer 16 choice sets. For more information on this part of a discrete choice experiment, see e.g. Reed Johnson et al. [24]. 
Overview of seasonal influenza and influenza A(H1N1)pdm09 policies per country, Netherlands, Poland, Spain, and Sweden, 2009 and 2013

\begin{tabular}{|c|c|c|c|c|}
\hline $\begin{array}{l}\text { Influenza type and } \\
\text { respective policies }\end{array}$ & Netherlands & Poland & Spain & Sweden \\
\hline \multicolumn{5}{|c|}{ Seasonal influenza [ 58 ] } \\
\hline \multirow{5}{*}{$\begin{array}{l}\text { Groups } \\
\text { recommended } \\
\text { for vaccination } \\
\text { during the 2012/13 } \\
\text { influenza season }\end{array}$} & NA & $\begin{array}{c}\text { Children and adolescents, aged } \geq 6 \\
\text { months }-<18 \text { years }\end{array}$ & NA & NA \\
\hline & Adults aged $\geq 60$ years & Adults aged $\geq 55$ years & $\begin{array}{l}\text { Adults aged } \geq 65 \\
\text { years }^{\mathrm{a}}\end{array}$ & Adults aged $\geq 65$ years \\
\hline & Medical risk groups ${ }^{\mathrm{b}}$ & Medical risk groups ${ }^{\mathrm{b}}$ & $\begin{array}{l}\text { Medical risk } \\
\text { groups }^{\mathrm{b}}\end{array}$ & Medical risk groups ${ }^{b}$ \\
\hline & $\begin{array}{l}\text { Pregnant women with } \\
\text { medical conditions }\end{array}$ & All pregnant women & $\begin{array}{l}\text { All pregnant } \\
\text { women }\end{array}$ & $\begin{array}{c}\text { Pregnant women in } 2^{\text {nd }} \text { or } 3^{\text {rd }} \\
\text { trimester }\end{array}$ \\
\hline & All HCWs & All HCWs & All HCWs & $\begin{array}{l}\text { HCWs caring for persons } \\
\text { who are severely } \\
\text { immunocompromised }\end{array}$ \\
\hline $\begin{array}{l}\text { Payment scheme } \\
\text { vaccine and } \\
\text { administration } \\
\text { during the } 2012 / 13 \\
\text { influenza season }\end{array}$ & $\begin{array}{l}\text { National health service } \\
\text { Employer pays for HCWs }\end{array}$ & $\begin{array}{l}\text { Payment scheme vaccine itself: } \\
\text { out-of-pocket; some employers pay } \\
\text { for HCWs; local governmentc } \\
\text { Payment scheme administration: } \\
\text { out-of-pocket; some employers pay } \\
\text { for HCWs; local government }{ }^{c} \\
\end{array}$ & $\begin{array}{l}\text { Regional health } \\
\text { service }\end{array}$ & $\begin{array}{l}\text { Regional health service; out- } \\
\text { of-pocket varies with regions }{ }^{d} \\
\text { Employer pays for HCWs }\end{array}$ \\
\hline $\begin{array}{l}\text { Vaccination } \\
\text { coverage during the } \\
2012 / 13 \text { influenza } \\
\text { season }\end{array}$ & $\begin{array}{c}\text { Overall adults aged } \geq 60 \\
\text { years: } 67.8 \%\end{array}$ & $\begin{array}{c}\text { Overall adults aged } \geq 65 \text { years: } 7.4 \% \\
\text { HCWs: } 9.5 \%\end{array}$ & $\begin{array}{c}\text { Overall adults } \\
\text { aged } \geq 65 \text { years: } \\
57 \% \\
\text { HCWs: } 22.9 \% \\
\end{array}$ & $\begin{array}{l}\text { Overall adults aged } \geq 65 \text { years: } \\
44 \%\end{array}$ \\
\hline \multicolumn{5}{|c|}{2009 influenza $\mathrm{A}\left(\mathrm{H}_{1} \mathrm{~N}_{1}\right)$ pdmo9 pandemic [ 19] } \\
\hline \multirow{5}{*}{$\begin{array}{l}\text { Groups } \\
\text { recommended for } \\
\text { vaccination during } \\
\text { the pandemic period }\end{array}$} & $\begin{array}{l}\text { Children aged } \geq 6 \text { months } \\
-4 \text { years, and household } \\
\text { members of babies up to } \\
\text { the age of } 6 \text { months }\end{array}$ & $\begin{array}{l}\text { Poland did not implement a } \\
\text { vaccination programme during the } \\
\text { influenza } A\left(\mathrm{H}_{1} \mathrm{~N} 1\right) \text { pdmo9 }\end{array}$ & NA & $\begin{array}{l}\text { Recommended for all children } \\
\text { aged } \geq 6 \text { months }-<18 \text { years }\end{array}$ \\
\hline & Adults aged $\geq 60$ years & NA & NA & Adults aged $\geq 18$ years \\
\hline & Medical risk groups ${ }^{\mathrm{b}}$ & NA & $\begin{array}{l}\text { Medical risk } \\
\text { groups }^{\mathrm{b}}\end{array}$ & Medical risk groups ${ }^{b}$ \\
\hline & $\begin{array}{l}\text { Pregnant women in } 2^{\text {nd }} \\
\text { and } 3^{\text {rd }} \text { trimester }\end{array}$ & NA & $\begin{array}{l}\text { All pregnant } \\
\text { women }\end{array}$ & All pregnant women \\
\hline & $\begin{array}{l}\text { HCWs with close contact } \\
\text { with patients } \\
\end{array}$ & NA & All HCWs & All HCWs \\
\hline Vaccine brand & Pandemrix, Focetria & NA & $\begin{array}{l}\text { Pandemrix, } \\
\text { Focetria, and } \\
\text { Panenza }\end{array}$ & Pandemrix \\
\hline Vaccination sites & \begin{tabular}{|} 
GPs, mass vaccination \\
sites in community \\
settings, Municipal Health \\
Services (children and \\
household contacts), and \\
work environment \\
\end{tabular} & NA & $\begin{array}{c}\text { GPs, hospital } \\
\text { settings, and } \\
\text { occupational health } \\
\text { services }\end{array}$ & $\begin{array}{l}\text { GPs, hospital settings, } \\
\text { outpatient care clinics, } \\
\text { occupational health services, } \\
\text { mass vaccination sites }\end{array}$ \\
\hline Payment scheme & $\begin{array}{c}\text { Free of charge for all } \\
\text { individuals recommended } \\
\text { the vaccine }\end{array}$ & NA & $\begin{array}{l}\text { Free of charge for } \\
\text { all individuals } \\
\text { recommended the } \\
\text { vaccine }\end{array}$ & $\begin{array}{l}\text { Free of charge for all } \\
\text { individuals recommended the } \\
\text { vaccine }\end{array}$ \\
\hline $\begin{array}{l}\text { Vaccination } \\
\text { coverage during the } \\
\text { pandemic period }\end{array}$ & $\begin{array}{c}\text { Entire population: } 30 \% \\
\text { Those at risk aged }>6 \\
\text { months: } 72 \% \\
\text { Pregnant women: } 58 \% \\
\text { HCWs: } 50 \%\end{array}$ & NA & $\begin{array}{c}\text { Entire population: } \\
27.1 \% \\
\text { Those at risk } \\
\text { aged }>6 \text { months: } \\
23.7 \% \\
\text { Pregnant women: } \\
9 \% \\
\text { HCWs: } 11.6 \%\end{array}$ & Entire population: $59 \%$ \\
\hline
\end{tabular}

GP: general practitioner; HCW: healthcare worker; NA: not applicable.

a Recommendation at the national level. However, 10 of 19 regions recommend vaccine for those $\geq 60$ years.

${ }^{b}$ Medical risk groups include e.g. patients with chronic pulmonary, cardiovascular and renal diseases, metabolic disorders, and immunosuppression due to disease or treatment (we refer to [1] for more details).

${ }^{c}$ Local government reimbursement of cost of vaccine and administration for those $\geq 65$ years of age.

${ }^{d}$ In some regions, the vaccine is charged a symbolic amount (ca 10 euros) for vaccine and vaccination. 
Attributes and attribute levels included in the survey investigating public preferences for vaccination programmes during pandemics caused by pathogens transmitted through respiratory droplets, Netherlands, Poland, Spain, and Sweden, 2013 ( $\mathrm{n}=7$ attributes)

\begin{tabular}{|c|c|}
\hline Scenario variables ${ }^{a}$ & Levels \\
\hline \multicolumn{2}{|l|}{ Pandemic scenario variables ${ }^{a}$} \\
\hline Susceptibility to the disease ${ }^{b}$ & $5 \%, 10 \%, 20 \%$ \\
\hline Severity of the disease ${ }^{c}$ & $5 \%, 25 \%, 50 \%, 75 \%$ \\
\hline \multicolumn{2}{|l|}{ Vaccination programme attributes ${ }^{d}$} \\
\hline Effectiveness of the vaccine & $30 \%, 50 \%, 70 \%, 90 \%$ \\
\hline \multirow{2}{*}{ Safety of the vaccine $e^{e}$} & Unknown, expected to be safe (reference level) \\
\hline & Unknown, no experience with similar vaccines yet \\
\hline \multirow{5}{*}{ Advice regarding the vaccine } & Family and/or friends recommend vaccination (reference level) \\
\hline & Family and/or friends discourage vaccination \\
\hline & Your doctor recommends vaccination \\
\hline & Your doctor discourages vaccination \\
\hline & Government and national institute of public health recommend vaccination \\
\hline \multirow{4}{*}{ Media attention about the vaccine ${ }^{f}$} & Traditional media positive (reference level) \\
\hline & Traditional media negative \\
\hline & Social and interactive media positive \\
\hline & Social and interactive media negative \\
\hline Out-of-pocket costsg & o euro, 50 euros, 100 euros \\
\hline
\end{tabular}

a The scenario variables were the same for all alternatives in one choice set.

${ }^{b}$ Defined as the proportion of population affected by the emerging disease, i.e. having symptoms.

${ }^{c}$ Defined as the proportion of the infected population that had severe symptoms or outcomes (death, life-threatening events, hospitalisation and severe or permanent disability).

${ }^{d}$ The attributes safety of the vaccine, advice about the vaccine and media attention about the vaccine were included in the latent class analysis as categorical variables.

e Safety of the vaccine with regard to long-term severe side effects (death, life-threatening events, hospitalisation, severe or permanent disability, or side effects leading to birth defects in an unborn fetus).

${ }^{\mathrm{f}}$ Traditional media were defined as radio, newspapers and television. Social and interactive media were defined as blogs, Twitter and social network websites.

$\mathrm{g}$ The levels presented in the Table are the selected levels for the Netherlands. Levels for the out-of-pocket costs attribute were converted to local currency of the other three countries and adapted according to the Organisation for Economic Co-operation and Development (OECD) price levels of May 2013 [26]. Levels of: o zloty, 120 zlotys, 240 zlotys for Poland; o euro, 45 euros and 90 euros for Spain and o kronor, 500 kronor, 1,000 kronor for Sweden.

The survey was first developed in Dutch and subsequently tested using think-a-loud interviews $(n=5)$ and a pen-and-paper pilot $(n=29)$. This resulted in some minor changes to the layout and phrasing of the Dutch survey. To be able to use the survey in the other countries, some further changes to the survey were made. For example, we adapted country naming, and currencies for the cost attribute based on Organisation for Economic Cooperation and Development (OECD) comparative price levels [25] of May 2013 [26]. Hereafter, the survey was translated into Polish, Spanish and Swedish. A second translator reviewed each translated survey. To minimise differences between the original Dutch and the translated versions of the survey and to check for inconsistencies, native speakers (speaking Dutch and the respective languages) translated each survey back into Dutch. In Spain, Sweden and Poland, we asked 30 respondents per country to complete the adapted and back-translated survey online and to give their suggestions for improvement. No suggestions were given. More details of the DCE for the current study have been described elsewhere [27].

\section{Data collection}

An ISO certified market research company (ISO 26362 [28], ISO 20252 [29], and ISO 14001 [30]), was hired to administer the online survey. This company used their own panel to collect data in the Netherlands, while another company's panels were used to collect data in the other three countries. Both companies follow international quality standards for market research [31]. Panel members were emailed an URL to the survey. Quota sampling was used to ensure that samples were representative for each country based on age, sex, educational level and region. We aimed to have 500 completed surveys per country in order to obtain reliable outcomes [32]. All respondents gave informed consent before participating in the study and received a small financial incentive in local currency for their contribution to the study from the research company. The amount differed per country according to what is 
TABLE 3

Characteristics of respondents who completed the survey per country, Netherlands, Poland, Spain, and Sweden, 2013

$(\mathrm{n}=2,068)$

\begin{tabular}{|c|c|c|c|c|c|c|c|c|c|c|c|c|}
\hline Characteristics & \multicolumn{3}{|c|}{$\begin{array}{l}\text { Netherlands } \\
(\mathrm{n}=536)\end{array}$} & \multicolumn{3}{|c|}{$\begin{array}{l}\text { Poland } \\
(\mathrm{n}=510)\end{array}$} & \multicolumn{3}{|c|}{$\begin{array}{l}\text { Spain } \\
(\mathrm{n}=512)\end{array}$} & \multicolumn{3}{|c|}{$\begin{array}{l}\text { Sweden } \\
(\mathrm{n}=510)\end{array}$} \\
\hline \multirow[t]{2}{*}{ Age median (IQ range) } & \multicolumn{3}{|c|}{$50(35-64)$} & \multicolumn{3}{|c|}{$41(28-55)$} & \multicolumn{3}{|c|}{$45(31-57)$} & \multicolumn{3}{|c|}{$50(35-59)$} \\
\hline & $N$ & $\%$ & $\%^{a}$ & $N$ & $\%$ & $\%^{a}$ & $N$ & $\%$ & $\%^{a}$ & $N$ & $\%$ & $\%^{a}$ \\
\hline \multicolumn{13}{|l|}{ Age groups (years) } \\
\hline $18-24$ & 49 & 9.1 & 11 & 95 & 19 & 14 & 59 & 12 & 10 & 58 & 11 & 11 \\
\hline $25-34$ & 78 & 15 & 16 & 95 & 19 & 19 & 95 & 19 & 21 & 69 & 14 & 16 \\
\hline $35-44$ & 84 & 16 & 19 & 101 & 20 & 16 & 97 & 19 & 20 & 77 & 15 & 18 \\
\hline $45-54$ & 107 & 20 & 19 & 90 & 18 & 20 & 79 & 15 & 16 & 112 & 22 & 16 \\
\hline$\geq 55$ & 218 & 41 & 35 & 129 & 25 & 30 & 182 & 36 & 33 & 194 & 38 & 39 \\
\hline Sex (male) & 289 & 54 & 49 & 261 & 51 & 48 & 251 & 49 & 49 & 245 & 48 & 49 \\
\hline Country of birth is the country of interest & 517 & 96 & $N A$ & 502 & 98 & $N A$ & 466 & 91 & $N A$ & 440 & 86 & $N A$ \\
\hline \multicolumn{13}{|l|}{ Educational level $^{\mathrm{b}}$} \\
\hline Lower education & 184 & 34 & 34 & 224 & 44 & 52 & 117 & 23 & 23 & 167 & 33 & 33 \\
\hline Average education & 192 & 36 & 40 & 199 & 39 & 34 & 156 & 30 & 31 & 179 & 35 & 34 \\
\hline Higher education & 160 & 30 & 26 & 87 & 17 & 14 & 239 & 47 & 46 & 164 & 32 & 33 \\
\hline \multicolumn{13}{|l|}{ Income ${ }^{c}$} \\
\hline Low income & 106 & 20 & $N A$ & 133 & 26 & $N A$ & 93 & 18 & $N A$ & 120 & 24 & $N A$ \\
\hline Average income & 127 & 24 & $N A$ & 127 & 25 & $N A$ & 239 & 47 & $N A$ & 256 & 50 & $N A$ \\
\hline High income & 181 & 34 & $N A$ & 250 & 49 & $N A$ & 180 & 35 & $N A$ & 134 & 26 & $N A$ \\
\hline Do not know or do not want to say & 122 & 23 & $N A$ & 0 & 0 & $N A$ & 0 & 0 & $N A$ & 0 & 0 & $N A$ \\
\hline Religious (yes) & 244 & 46 & $N A$ & 403 & 79 & $N A$ & 250 & 49 & $N A$ & 191 & 37 & $N A$ \\
\hline Working in healthcare (yes) & 56 & 10 & $N A$ & 20 & 4 & $N A$ & 33 & 6 & $N A$ & 48 & 9 & $N A$ \\
\hline \multicolumn{13}{|l|}{ Perception of own health } \\
\hline Worse health than average & 41 & 8 & $N A$ & 40 & 8 & $N A$ & 36 & 7 & $N A$ & 44 & 9 & $N A$ \\
\hline Medium health & 195 & 36 & $N A$ & 165 & 32 & $N A$ & 214 & 42 & $N A$ & 151 & 30 & $N A$ \\
\hline Better health than average & 300 & 56 & $N A$ & 305 & 60 & $N A$ & 262 & 51 & $N A$ & 315 & 62 & $N A$ \\
\hline \multicolumn{13}{|l|}{ Seasonal influenza vaccine target group } \\
\hline Yes & 239 & 45 & $N A$ & 85 & 17 & $N A$ & 168 & 33 & $N A$ & 136 & 27 & $N A$ \\
\hline No & 270 & 50 & $N A$ & 382 & 75 & $N A$ & 300 & 59 & $N A$ & 321 & 63 & $N A$ \\
\hline No, but receives vaccination via work & 27 & 5 & $N A$ & 43 & 8 & $N A$ & 44 & 9 & $N A$ & 53 & 10 & $N A$ \\
\hline $\begin{array}{l}\text { Received seasonal influenza vaccination last year (yes, for } \\
\text { persons belonging to target group) }\end{array}$ & 156 & 65 & $N A$ & 34 & 40 & $N A$ & 97 & 58 & $N A$ & 56 & 41 & $N A$ \\
\hline
\end{tabular}

IQ: interquartile; NA: not applicable.

${ }^{a}$ Census data per country.

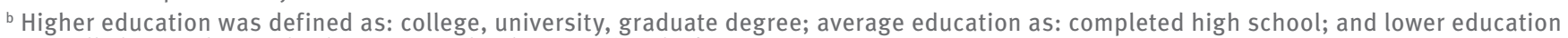
as: all else, such as only elementary school or vocational education.

' Income was defined as: low ( $(23,000$ euros), average (23,000-34,000 euros), high ( $>34,000$ euros) per year for the Dutch sample; low ( 2,000 zlotys), average (2,000-3,000 zlotys), high ( $>3,000$ zlotys) per month for the Polish sample; low (<999 euros), average (1,0002,000 euros), high ( $>2,000$ euros) per month for the Spanish sample; and low ( $(175,000$ kronor), medium (175,000-500,000 kronor), high (>500,000 kronor) per year for the Swedish sample.

customary in the given country (e.g. Dutch respondents were paid 2.20 euros). Data collection took place between June and September 2013. A declaration of no objection was received from the Medical Ethics Committee of the Erasmus MC, University Medical Center Rotterdam (MEC-2012-263) after they reviewed the study protocol. According to Dutch legislation, the methodology of this study, a survey among volunteers of Internet panels, does not fall within the scope of the Medical Research Involving Human Subjects Act [33]. Although the aim of the study is of medical nature, respondents are not being subjected to any treatment or behavioural adjustments.

\section{Data analysis}

The choice observations resulting from the DCE were used to estimate the impact of pandemic scenario variables and vaccination programme attributes (independent variables) on the respondents' choices for vaccination or opting-out (dependent variable). A significant independent variable in this choice model indicates that the attribute or attribute level has a significant impact on vaccination preferences and the 
TABLE 4

Regression coefficients for three latent classes based on responses to a survey investigating public preferences for vaccination programmes during pandemics caused by pathogens transmitted through respiratory droplets, Netherlands, Poland, Spain, and Sweden, $2013(\mathrm{n}=2,068)^{\mathrm{a}, \mathrm{b}, \mathrm{c}}$

\begin{tabular}{|c|c|c|c|c|c|c|}
\hline \multirow[b]{2}{*}{ Parameters } & \multicolumn{2}{|c|}{ Class 1} & \multicolumn{2}{|c|}{ Class 2} & \multicolumn{2}{|c|}{ Class 3} \\
\hline & $\begin{array}{l}\text { Coefficient } \\
(p \text {-value })\end{array}$ & $S E$ & $\begin{array}{l}\text { Coefficient } \\
\text { (p-value) }\end{array}$ & $S E$ & $\begin{array}{l}\text { Coefficient } \\
\text { (p-value) }\end{array}$ & SE \\
\hline \multicolumn{7}{|l|}{ Choice model } \\
\hline Constant (vaccination) & $0.70(* \star *)$ & 0.04 & $-0.79(* \star \star)$ & 0.03 & $-5.02(* \star *)$ & 0.27 \\
\hline Effectiveness of vaccination (per $10 \%$ ) & $0.18(* \star *)$ & 0.01 & $-0.03(* \star \star)$ & 0.01 & 0.06 (NS) & 0.05 \\
\hline Side effects unknown, but expected to be safe (reference) & 0.16 (Ref) & 0.01 & 0.17 (Ref) & 0.01 & 0.22 (Ref) & 0.08 \\
\hline Side effects unknown, no experience yet & $-0.16(* \star *)$ & 0.01 & $-0.17(* \star \star)$ & 0.01 & $-0.22(* \star *)$ & 0.08 \\
\hline Family and/or friends recommend (reference) ${ }^{\mathrm{d}}$ & -0.22 (Ref) & 0.02 & -0.14 (Ref) & 0.02 & 0.33 (Ref) & 0.16 \\
\hline Family and/or friends discourage & $-0.34(* \star *)$ & 0.02 & $-0.46(* \star *)$ & 0.03 & $-0.41(* \star)$ & 0.19 \\
\hline Your doctor recommends & $0.18(* * *)$ & 0.02 & $0.40(* \star *)$ & 0.02 & $0.50(* * *)$ & 0.15 \\
\hline Your doctor discourages & $\left.-0.47^{(\star \star \star}\right)$ & 0.02 & $\left.-0.75^{(* \star *}\right)$ & 0.03 & $-1.05(* \star *)$ & 0.28 \\
\hline Government and public health institutions recommend & $0.44(* \star *)$ & 0.02 & $0.52(* \star \star)$ & 0.02 & $\left.0.35^{(* *}\right)$ & 0.17 \\
\hline International organisations recommend & $0.40(* * *)$ & 0.02 & $0.42(* \star *)$ & 0.02 & $0.27\left(^{*}\right)$ & 0.15 \\
\hline Traditional media is positive (reference) & $0.03(\operatorname{Ref})$ & 0.01 & 0.22 (Ref) & 0.02 & $0.33($ Ref $)$ & 0.12 \\
\hline Traditional media is negative & $-0.12(\star \star \star)$ & 0.02 & $-0.22(\star \star \star)$ & 0.00 & $-0.41(* \star \star)$ & 0.15 \\
\hline Social / interactive media is positive & $0.12(* \star \star)$ & 0.02 & $0.18(\star \star \star)$ & 0.00 & $0.22\left(^{\star}\right)$ & 0.12 \\
\hline Social / interactive media is negative & -0.02 (NS) & 0.02 & $-0.18(* \star \star)$ & 0.00 & $-0.14(\mathrm{NS})$ & 0.14 \\
\hline Out-of-pocket costs of the vaccine (per 10 euros) & $-0.04(* \star \star)$ & 0.00 & $-0.13(* * *)$ & 0.00 & $-0.14(* \star \star)$ & 0.02 \\
\hline $\begin{array}{l}\text { Interaction: effectiveness of vaccine (per } 10 \%) \mathrm{x} \\
\text { susceptibility to the disease (per } 100 \text { of } 1,000 \text { persons) }\end{array}$ & $\left.0.07^{(\star \star \star}\right)$ & 0.01 & $0.12(* * *)$ & 0.00 & $0.12(* * \star)$ & 0.02 \\
\hline $\begin{array}{l}\text { Interaction: effectiveness of vaccine (per } 10 \%) \text { x severity of } \\
\text { the disease (per } 10 \%)\end{array}$ & $0.01(* \star *)$ & 0.00 & $0.02(* \star *)$ & 0.00 & $0.01(* \star)$ & 0.00 \\
\hline \multicolumn{7}{|l|}{ Class membership model ${ }^{\mathrm{e}}$} \\
\hline Constant & $-0.08(\mathrm{NS})$ & 0.10 & $0.00(\mathrm{NA})$ & 0.00 & $-0.83(* \star *)$ & 0.13 \\
\hline The Netherlands (reference) & 0.00 (Ref) & 0.00 & 0.00 (Ref) & 0.00 & 0.00 (Ref) & 0.00 \\
\hline Poland & $0.64(\star \star \star)$ & 0.15 & $0.00(\mathrm{NA})$ & 0.00 & 0.07 (NS) & 0.20 \\
\hline Spain & $0.60(\star \star \star)$ & 0.15 & $0.00(\mathrm{NA})$ & 0.00 & 0.12 (NS) & 0.19 \\
\hline Sweden & -0.09 (NS) & 0.16 & $0.00(\mathrm{NA})$ & 0.00 & $0.86(* \star *)$ & 0.17 \\
\hline Class probability ${ }^{f}$ & \multicolumn{2}{|c|}{ Proportion (RR) } & \multicolumn{2}{|c|}{ Proportion (RR) } & \multicolumn{2}{|c|}{ Proportion (RR) } \\
\hline Average & \multicolumn{2}{|c|}{$0.44(1.00)$} & \multicolumn{2}{|c|}{$0.35(1.00)$} & \multicolumn{2}{|c|}{$0.21(1.00)$} \\
\hline Respondents from the Netherlands & \multicolumn{2}{|c|}{$0.39(0.89)$} & \multicolumn{2}{|c|}{$0.42(1.21)$} & \multicolumn{2}{|c|}{$0.18(0.86)$} \\
\hline Respondents from Poland & \multicolumn{2}{|c|}{$0.55(1.24)$} & \multicolumn{2}{|c|}{$0.31(0.89)$} & \multicolumn{2}{|c|}{$0.14(0.69)$} \\
\hline Respondents from Spain & \multicolumn{2}{|c|}{$0.53(1.20)$} & \multicolumn{2}{|c|}{$0.32(0.90)$} & \multicolumn{2}{|c|}{$0.16(0.74)$} \\
\hline Respondents from Sweden & \multicolumn{2}{|c|}{$0.30(0.67)$} & \multicolumn{2}{|c|}{$0.35(0.99)$} & \multicolumn{2}{|c|}{$0.36(1.70)$} \\
\hline \multicolumn{7}{|l|}{ Model fitg,h } \\
\hline Akaike Information Criterion (AIC) & \multicolumn{6}{|c|}{1.54} \\
\hline Pseudo- $R^{2}$ & \multicolumn{6}{|c|}{0.30} \\
\hline
\end{tabular}

SE: standard error; NA: not applicable; NS: non-significant coefficient; Ref: reference; RR: relative risk.

${ }^{a}$ Effects coded variables used for the safety of the vaccine, advice about the vaccine, media attention about the vaccine.

' The values of the vaccination programme attributes' reference levels equals the negative sum of the coefficients of the included attribute.

$c * \star *, * \star, *$ denotes significance at the $1 \%$ and $5 \%$ and $10 \%$ level respectively.

${ }^{d}$ Note that for class 2 and 3 , the recommendation of family and/or friends had a negative effect on utility. However, the utility is still positive compared with discouraging of family and/or friends.

e Class 2 does not have parameters in the class membership model as the parameters of class 1 to 3 are relative to class 2.

${ }^{f}$ The relative risks represent the relative probability of someone belonging to that class compared with the average class probability.

${ }^{g}$ Note that the pseudo- $R^{2}$ is not the same as the $R^{2}$ that is used in a linear regression model. A pseudo- $R^{2}$ of $0.3-0.4$ is equivalent to a $R^{2}$ between 0.6 and $0.8[21]$.

${ }^{\text {h }}$ A model with 3 classes is presented in the Table. This model had significantly better fit compared with a model with 2 classes (AIC: 1.64 , pseudo- $\mathrm{R}^{2}:$ 0.26). Although a latent class model with 4 classes had an improved fit (AIC: 1.50, pseudo- $\mathrm{R}^{2}: 0.32$ ), we opted for a model with 3 classes to be able to explain the results to policymakers in a clear manner. 
sign of the coefficient reflects whether this impact has a positive or negative effect. Note that pandemic scenario variables could only be included as an interaction effect, as the scenario was the same in the three alternatives presented in each choice set. Several types of discrete choice models can be estimated. We chose a latent class model, since this is a closed form model (i.e. does not rely on complex simulations) that can take the panel nature of the data into account (i.e. dependencies between choice observations by a single respondent) [34].

A latent class analysis assumes the existence of subgroups (i.e. classes) of respondents with homogenous preferences. The researcher pre-specifies the number of classes based on the best model fit using the Akaike Information Criterion (AIC) and sound interpretation of classes. Class membership is latent in that the researcher does not determine who belongs to which class a priori. Instead, class membership is expressed by class probabilities that may depend on the respondent's characteristics. In addition to the choice model, we fitted a class membership model to test whether class membership is dependent on country of residence. Using the output of the class membership model, the class probabilities adjusted for country of residence can be calculated.

Calculation of the relative importance of the attributes enables a direct comparison of preferences between classes. The percentages represent the proportion of someone's preference (utility) that is based on that attribute. The relative importance can be calculated by dividing the difference in coefficient values between the highest and lowest level for a single attribute by the sum of the differences of all attributes for that class, considering interaction effects [35]. The mean expected uptake of a vaccine per class was calculated by taking the exponent of the total utility for vaccination divided by the exponent of utility of both vaccination and no vaccination. We were able to calculate these uptakes per country, by weighing the class-specific uptake with the class probabilities per country. The relative importance of the attributes and the expected vaccination uptake were calculated for two pandemic scenarios: a mild scenario in which $5 \%$ of the population gets the disease (susceptibility to the disease), and $5 \%$ of the sick people developing severe symptoms (severity of the disease), and a severe scenario in which $20 \%$ of the population gets the disease, and $75 \%$ of the sick people develops severe symptoms.

We used NLogit 4.0 software to estimate the latent class model and SPSS 21.0 software for all other analyses, such as chi-squared tests to compare proportions between countries.

\section{Results}

\section{Study population}

In total 7,272 panel members were invited to participate in the study. Of these, 2,651 started the survey (response rates ranged from $29 \%(627 / 2,186)$ for Spanish panel members up to $63 \%(677 / 1,083)$ for Dutch panel members; Figure 1). Of those who started, 2,068 completed the survey, ranging from $73 \%(510 / 698)$ of Swedish panel members up to $82 \%(512 / 627)$ of Spanish panel members. The country samples were approximately representative regarding age, sex, educational level and region (Table 3). However, compared with national census data, lower educated Poles were slightly underrepresented as well as respondents from the western region of Spain.

Respondents took a mean of 19 min (standard deviation: $31 \mathrm{~min}$ ) to complete the survey. The majority of the respondents indicated that the survey topic was interesting or very interesting $(81 \% ; 1,677 / 2,068)$, and clear or very clear $(74 \% ; 1,528 / 2,068)$. A minority of respondents $(9 \% ; 179 / 2,068)$ found the survey hard or very hard to complete (ranging from $5 \%(28 / 510)$ for Poland to $13 \%(72 / 536)$ for the Netherlands). The proportion of choice sets in which the 'no vaccination' alternative was chosen was highest in the Swedish sample $\left(51 \% ; 4,145 /\left(16^{\star} 510=8,160\right)\right)$. The proportion of respondents that chose the 'no vaccination' alternative in all 16 choice sets was also higher in the Swedish sample $(27 \%(136 / 510), p<0.01)$ than elsewhere $(10 \%$ for Poland (52/510) and Spain (54/512), and $11 \%$ $(61 / 536)$ for the Netherlands). Additionally, the proportion of respondents that always opted for vaccination was lowest in the Swedish sample $(16 \% ; 81 / 510)$, and highest in the Spanish sample (31\%; 161/512).

\section{Latent class analysis}

Three latent classes, numbered from one to three, were identified (Table 4). The average class probability was $0.44,0.35$ and 0.21 , for class 1,2 , and 3 respectively. The country of residence partly explains class membership, which is an indication for preference heterogeneity between countries. Respondents from Poland and Spain had a significantly higher chance to belong to class 1 ( 0.55 and 0.53 respectively, p<0.01) than respondents from other countries, those from the Netherlands had a significantly higher chance to belong to class $2(0.42, p<0.01)$, and those from Sweden to class $3(0.36, p<0.01)$.

Irrespective of the class they belonged to, respondents preferred a more effective vaccine that is expected to be safe, recommended by others, discussed positively in the media and with lower out-of-pocket costs, as can be seen by the positive and negative signs of the coefficients. The significant constant in all three classes indicates that, without considering any vaccination programme attributes, respondents of class 2 and 3 had a rather negative attitude towards vaccination, while respondents belonging to class $1 \mathrm{did}$ 
not. Almost all vaccination programme attributes were significant. The positive recommendation of international organisations did not significantly explain preferences of respondents within class 3 . The coefficient for social/interactive media attention was not significantly different from positive traditional media attention for respondents of class 3 (both positive and negative social/interactive media attention) and class 1 (only negative social/interactive media attention), meaning that social media only marginally influences respondents' preferences for vaccination. Significant interaction effects between both susceptibility to and severity of the disease, and effectiveness of the vaccine in all classes indicate that the preference for the level of effectiveness of a vaccine is dependent on the seriousness of the pandemic. In other words, the more serious the pandemic, while the effectiveness of a vaccination remains the same, the more the preference for vaccination increases relative to no vaccination.

\section{Relative importance}

In the case of a mild scenario, the two most important attributes for class 2 and 3 were advice regarding vaccination and out-of-pocket costs, while effectiveness of the vaccine and advice regarding vaccination were the most important attributes for class 1 (Figure 2). Although advice regarding vaccination was important irrespective of class membership, for respondents belonging to class 3 , the advice of friends and/or family and the advice of physicians were most important for vaccination choice (based on differences between coefficients of advice regarding vaccine), while the advice of both national and international health authorities was important for respondents belonging to class 1. Additionally, all respondents were more sensitive to advice against compared with advice in favour of vaccination. The relative importance of attributes varied with the seriousness of the pandemic scenario. Effectiveness was the most important attribute in the case of a severe scenario in all the latent classes and not only for respondents from class 1.

\section{Predicted vaccine uptake}

Assuming a realistic vaccination programme (i.e. a vaccination that is $70 \%$ effective, expected to be safe, recommended by family and/or friends, positively discussed in traditional media, and without out-ofpocket costs), the mean expected uptake in the case of a mild scenario was lowest for Swedish respondents with 43\% (220/510; 95\% confidence interval (Cl): $40-47 \%)$ ), followed by $54 \%(292 / 536 ; 95 \% \mathrm{Cl}$ : $51-58 \%)$ for Dutch respondents, 62\% (318/512; 95\% $\mathrm{Cl}: 59-65 \%)$ for Spanish respondents, and highest for respondents from Poland with 63\% (323/510, 95\% Cl: $60-66 \%)$. In the case of a mild scenario, advice regarding the vaccine and out-of-pocket costs had a relatively large impact on vaccination uptake in all countries, while media attention had little effect on uptake. For example, when out-of-pocket costs increased from o to 100 euros, the uptake decreased to $32 \%(163 / 510$; $95 \% \mathrm{Cl}: 29-35 \%)$ for Swedish respondents, followed by $41 \%(222 / 536 ; 95 \% \mathrm{Cl}: 38-45 \%)$ for Dutch respondents, 51\% (263/512; 95\% Cl: 48-55\%) for Spanish respondents, and 53\% (269/510; 95\% Cl: 49-56\%) for Polish respondents. The uptake rates were expected to increase dramatically in the case of a severe scenario with up to $65 \%(331 / 510 ; 95 \% \mathrm{Cl}: 61-69 \%)$ for respondents from Sweden, and 82\% (419/510; 95\% Cl: $80-85 \%)$ for respondents from Poland.

\section{Discussion}

\section{Statement of principal findings}

In the case of a severe pandemic scenario, vaccine effectiveness was the most important characteristic determining vaccination preference in all countries. The body that advises a vaccine was found to strongly affect preferences in all countries as well, with respondents being more sensitive to advice against compared with advice in favour of vaccination. Preference heterogeneity between countries was substantial, especially in the case of a mild pandemic scenario; a strong effect on vaccine preferences was found for the advice of family and/or friends and the advice of physicians in Sweden, in contrast to Poland and Spain, where the advice of (international) health authorities was more important. Besides the vaccination advice, outof-pocket costs were important for Dutch and Swedish respondents, while for respondents from Poland and Spain the effectiveness of the vaccine was important in case of a mild pandemic scenario. Irrespective of pandemic scenario or programme attributes, the predicted vaccination uptakes were lowest in Sweden, and highest in Poland.

\section{Strengths and weaknesses of the study}

So far, only a limited number of healthcare-related DCEs have quantitatively compared preferences between respondents from different countries and this is, to our best knowledge, done for the first time in the field of infectious diseases. An additional strength is the advanced analysis technique we used in this study. While already used extensively in the field of transport economics, latent class analysis has been used for only $3 \%$ of all health-related DCE analyses conducted between 2009 and 2012 [23]. A possible weakness of our study is that the preferences are stated and based on hypothetical pandemic scenarios. Respondents might have given socially desirable responses. It is not known to what extent the stated preferences differ from preferences during an actual pandemic. However, the external validity of the DCE method has been studied in other health related contexts, and results are encouraging with respect to prediction of preferences on an aggregate level $[36,37]$. In addition, the hypothetical nature of the study enabled us to compare preferences between different possible future pandemic scenarios. The findings might thus help to prepare for a future pandemic. Additionally, all coefficients had the expected sign, which suggests theoretical validity of the DCE [38]. Another possible weakness is the complexity of the choice sets, due to inclusion of risks 
as attributes. However, we thoroughly pilot tested the survey and, during the online survey, only a minority of respondents stated that they experienced problems completing the choice sets.

\section{Results in relation to other studies}

Our study showed that the expected vaccination uptake is largely dependent on the seriousness of a pandemic. This was also shown in previous studies, including studies conducted in the Netherlands, Poland, Spain and Sweden [39-45]. During the influenza $A\left(\mathrm{H}_{1} \mathrm{~N}_{1}\right)$ pdmog pandemic, the perceived vulnerability was low and respondents believed that they were less likely to become infected than other people $[41,46]$. This might have been one of the reasons for the lower than expected uptake during that pandemic with overall, $30 \%, 27 \%$ and $59 \%$ of the Dutch, Spanish and Swedish population respectively, having been vaccinated (Table 1). Interestingly, we found that Swedish respondents were least willing to get vaccinated in future influenza pandemics, both in mild and severe scenarios. As previous experiences are likely to influence future vaccination uptake [45], the difference between our study results and actual influenza $A\left(\mathrm{H}_{1} \mathrm{~N}_{1}\right)$ pdmog vaccination coverage might be assigned to the negative experiences Swedish citizens had with vaccination during the 2009 pandemic. In Sweden, the controversy on the association between pandemic vaccines and narcolepsy is still ongoing [47]. In addition, Swedish respondents in the current study less often had received seasonal influenza vaccination in the previous year compared with e.g. Dutch respondents ( $41 \%$ vs $65 \%$, Table 3 ). Research, conducted in the Netherlands, has shown that trust in health authorities is related to pandemic influenza vaccination uptake [48] and that it is necessary to build up and sustain trust before, during and after an influenza pandemic [16]. Furthermore, during the influenza $A\left(\mathrm{H}_{1} \mathrm{~N}_{1}\right)$ pdmog pandemic Dutch and Swedish participants had more trust in healthcare professionals compared with Polish and Spanish participants [18]. Our research shows the same inter-country differences. Poland did not implement a national vaccination programme during the influenza $A\left(\mathrm{H}_{1} \mathrm{~N}_{1}\right)$ pdmog pandemic $[15,44]$ (Table 1). Seasonal influenza vaccination coverage is reported to be less than $10 \%$ for the target population older than 55 years [49]. Reported reasons for the Polish public to reject influenza (both seasonal and pandemic) vaccination include the low level of confidence in the quality and effectiveness of the vaccine $[18,50]$. Our finding that effectiveness of a pandemic vaccine had by far the strongest effect on vaccination choice of Polish respondents, confirmed this. The lowest seasonal influenza vaccination coverage contrasts with our finding that Polish respondents were more willing to get vaccinated than respondents from other countries. However, in our study, the level of effectiveness of the vaccine was presented to respondents as a known rate, which might explain why we estimated a higher vaccination uptake. Safety of the pandemic vaccine was not as dominant in the current study as in other studies $[39,40]$. The choice of attribute levels for our DCE might explain this difference in relative importance. We included realistic attribute levels, instead of presenting a certain vaccination risk (e.g. 1 in 100,000) to respondents. We also analysed safety as an interaction with the pandemic scenario variable 'severity of the disease', but with no meaningful outcome. We found almost no effect of social media attention (compared to traditional media) on pandemic vaccination preferences and predicted uptake. The objective framing of this attribute in the DCE survey might explain the finding. However, social media will likely be influential in future pandemics in other ways, e.g. by creating online applications that provide credible health information [51].

\section{Implications for clinicians and policymakers}

Our results show that seriousness of a pandemic influences vaccination uptake dramatically. In order to increase pandemic vaccination coverage, it is essential that susceptible people feel susceptible and perceive the pandemic as a serious threat. This can be achieved, for example, by honest and open communication regarding the seriousness of the pandemic, and avoiding conflicting messages and information overload $[17,52]$ and by providing public health messages that include descriptive and injunctive normative information [53,54]. The WHO Regional Office for Europe and the European Centre for Disease Prevention and Control (ECDC) recommend more flexible pandemic preparedness planning, i.e. planning that takes into account different pandemic scenarios $[8,9,19]$. Findings of our study may facilitate responses to future influenza pandemics with different levels of severity, as our study provides the option to calculate the expected vaccination uptake for different pandemic scenarios, and provides insights into how several vaccination programme attributes influence these uptakes. Additionally, our study also shows that the availability of an effective pandemic vaccine is of paramount importance in order to reach certain coverage levels. Unfortunately, such a highly effective vaccine might not be available due to the crisis situation that is inherent to a pandemic, or proof that the vaccine is effective might be lacking as time is usually limited. In addition, due to contracts or limited availability of vaccines, there are usually only one or two different vaccines available for policymakers to choose from. For all countries, given the high impact of vaccine effectiveness on vaccination preferences, it is therefore important that there is open communication regarding the expected effectiveness, so that the public can make an informed choice whether to get vaccinated or not. The vaccination programme attributes that can be influenced by policymakers directly are out-of-pocket costs and how/what to communicate. As our results show that by whom a vaccine is advised had a different effect on uptake in the included countries, it is important that during future pandemics the responsible authorities align with other important stakeholders in the country and communicate in a coordinated manner. 
Unanswered questions and further research

We found different in preferences for pandemic vaccinations between difference European countries. Further research could focus on differences within these countries, e.g. whether preferences of those who previously received seasonal influenza vaccination differ from preferences of those who had not, as previous research shows that the uptake of seasonal influenza vaccination was positively associated with influenza $\mathrm{A}\left(\mathrm{H}_{1} \mathrm{~N}_{1}\right)$ pdmog vaccination decision-making $[39,55,56]$. Additionally, future research could focus on subgroups of the population, such as healthcare workers or undervaccinated groups. It is unknown whether preferences differ between countries within the same geographical area of Europe. Therefore, it might be useful to conduct the same DCE in other European countries as well. Unfortunately, timely access to vaccinations is not self-evident [57]. It is not known in advance which respiratory pathogen will cause a next pandemic and production capacities might be inadequate. In the case of an influenza pandemic, other preventive measures such as quarantine, and antiviral drugs might be helpful to limit the spread of the virus during the first phase [10]. Further research into preferences for other preventive measures, and differences herein across European countries, using the DCE methodology is thus recommended. Moreover, the DCE methodology could also be used to study motivations and barriers for vaccinations other than pandemic vaccination among different countries.

\section{Acknowledgements}

The study was conducted in the context of the FP7 ECOM project. ECOM is the acronym for Effective Communication in Outbreak Management: Development of an evidence-based tool for Europe. By integrating social, behavioural, communication, and media sciences, researchers aim to develop an evidence-based behavioural and communication strategy for health professionals and agencies throughout Europe in case of major outbreaks (http://www.ecomeu.info/).

The research leading to these results has received funding from the European Union Seventh Framework Programme (FP7/2007-2013) under grant agreement no. 278763. The funders had no role in study design; in the collection, analysis and interpretation of data; in writing the report and in the decision to submit the article for publication.

We would like to thank all the people involved in the design of the questionnaire, especially all native speakers for their contribution, and all ECOM project members. We would like to thank Marcel Jonker for his support in the calculations of the $95 \%$ confidence intervals for the predicted vaccination uptake.

\section{Conflict of interest}

None declared.

\section{Authors' contributions}

All authors made substantial contributions to the acquisition and/or design of the study. DD, IK and EBG collected the data and performed the analysis of the collected data. All authors have contributed to the interpretation of the data. DD, together with EBG, drafted the manuscript. IK, AF, ES, MB, HV, $J R$, and $M L$ have critically revised the manuscript. All authors read and approved the final manuscript.

\section{References}

1. Taubenberger JK, Morens DM. 1918 Influenza: the mother of all pandemics.Emerg Infect Dis. 2006;12(1):15-22. DOI: 10.3201/ eid1209.05-0979 PMID: 16494711

2. European Centre for Disease Prevention and Control (ECDC). The influenza $A\left(\mathrm{H}_{1} \mathrm{~N}_{1}\right)$ pandemic in Europe. Stockholm: ECDC; 2010. Available from: http://ecdc.europa.eu/en/publications/ Publications/101108_SPR_pandemic_experience.pdf

3. Kilbourne ED. Influenza pandemics of the 2oth century.Emerg Infect Dis. 2006;12(1):9-14. DOI: 10.3201/eid1201.051254 PMID: 16494710

4. Nicoll A, Ammon A, Amato Gauci A, Ciancio B, Zucs P, Devaux I, et al. Experience and lessons from surveillance and studies of the 2009 pandemic in Europe. Public Health. 2010;124(1):1423. DOI: 10.1016/j.puhe.2009.12.001 PMID: 20141821

5. European Centre for Disease Prevention and Control (ECDC), Known facts and known unknowns. Stockholm: ECDC; 2010 [Accessed 21 Oct 2015]. Available from: http://ecdc.europa. eu/en/healthtopics/Documents/0905_Pandemic_Influenza_ Known_Facts_and_Known_Unknowns.pdf

6. World Health Organization (WHO). WHO global influenza preparedness plan: the role of WHO and recommendations for national measures before and during pandemics. Geneva: WHO; 2005. Available from: http://www.who.int/csr/resources/ publications/influenza/WHO_CDS_CSR_GIP_2005_5.pdf

7. Fineberg HV. Pandemic preparedness and response-lessons from the $\mathrm{H}_{1} \mathrm{~N}_{1}$ influenza of 2009.N Engl J Med. 2014;370(14):1335-42. DOI: 10.1056/NEJMra1208802 PMID: 24693893

8. Nicoll A, Brown C, Karcher F, Penttinen P, HegermannLindencrone $M$, Villanueva $S$, et al. Developing pandemic preparedness in Europe in the 21st century: experience, evolution and next steps. Bull World Health Organ. 2012;90(4):311-7. DOI: 10.2471/BLT.11.097972 PMID: 22511829

9. World Health Organization Regional Office for Europe (WHO/ Europe), European Centre for Disease Prevention and Control $(E C D C)$. Key changes to pandemic plans by Member States of the WHO European Region based on lessons learnt from the 2009 pandemic. WHO/Europe and ECDC; 2012. Available from: http://www.euro.who.int/_data/assets/ pdf_file/0006/161664/ECDC_WHO_EURO_PiP-WorkshopsSummary-Report_FINAL-26032012.pdf?ua=1

10. Longini IM, Nizam A, Xu S, Ungchusak K, Hanshaoworakul W, Cummings DA, et al. Containing pandemic influenza at the source. Science. 2005;309(5737):1083-7. DOI: 10.1126/ science.1115717 PMID: 16079251

11. Ferguson NM, Cummings DA, Fraser C, Cajka JC, Cooley PC, Burke DS. Strategies for mitigating an influenza pandemic. Nature. 2006;442(7101):448-52. DOI: 10.1038/nature04795 PMID: 16642006

12. Germann TC, Kadau K, Longini IM, Macken CA. Mitigation strategies for pandemic influenza in the United States.Proc Natl Acad Sci USA. 2006;103(15):5935-40. DOI: 10.1073/ pnas.0601266103 PMID: 16585506

13. Lugnér AK, van Boven M, de Vries R, Postma MJ, Wallinga J. Cost effectiveness of vaccination against pandemic influenza in European countries: mathematical modelling analysis. BMJ. 2012;345(jul12 3):e4445. DOI: 10.1136/bmj.e4445 PMID: 22791791

14. Valenciano M, Kissling E, Cohen JM, Oroszi B, Barret AS, Rizzo C, et al. Estimates of pandemic influenza vaccine effectiveness in Europe, 2009-2010: results of Influenza Monitoring Vaccine Effectiveness in Europe (I-MOVE) multicentre case-control study. PLoS Med. 2011;8(1):e1000388. DOI: 10.1371/journal.pmed.1000388 PMID: 21379316

15. Mereckiene J, Cotter S, Weber JT, Nicoll A, D’Ancona F, Lopalco $\mathrm{PL}$, et al. , VENICE project gatekeepers group. Influenza $A\left(\mathrm{H}_{1} \mathrm{~N}_{1}\right)$ pdmo9 vaccination policies and coverage in Europe. Euro Surveill. 2012;17(4):20064.PMID: 22297139

16. Gesser-Edelsburg A, Mordini E, James JJ, Greco D, Green MS. Risk Communication Recommendations and Implementation During Emerging Infectious Diseases: A Case Study of the 2009 H1N1 Influenza Pandemic.Disaster Med Public Health Prep. 2014;8(02): 158-69. DOI: 10.1017/dmp.2014.27 PMID: 24735822 
17. Larson HJ, Cooper LZ, Eskola J, Katz SL, Ratzan S. Addressing the vaccine confidence gap.Lancet. 2011;378(9790):526-35. DOI: 10.1016/S0140-6736(11)60678-8 PMID: 21664679

18. Influenza $\mathrm{H}_{1} \mathrm{~N}_{1}$ Analytical Report - Eurobarometer on Influenza $\mathrm{H}_{1} \mathrm{~N}_{1}$. The Gallup Organization; 2010. Available from: http:// ec.europa.eu/public_opinion/flash/fl_287_en.pdf

19. O'Flanagan D, Cotter S, Mereckiene J. Pandemic A(H1N1) 2009 Influenza Vaccination Survey, Influenza season 2009/2010. VENICE II Consortium; 2011. Available from: http://venice. cineca.org/Final_Report_VENICE_Pandemic_Influenza_2009. pdf

20. Ryan M. Discrete choice experiments in health care.BMJ. 2004;328(7436):360-1. DOI: 10.1136/bmj.328.7436.360 PMID: 14962852

21. Hensher DA, Rose JM, Greene WH. Applied choice analysis: a primer. Cambridge: Cambridge University Press; 2005.

22. Luce D, Tukey J. Simultaneous conjoint measurement: a new type of fundamental measurement.J Math Psychol. 1964;1(1):127. DOI: $10.1016 / 0022-2496(64) 90015-X$

23. Clark MD, Determann D, Petrou S, Moro D, de Bekker-Grob EW. Discrete choice experiments in health economics: a review of the literature.Pharmacoeconomics. 2014;32(9):883-902. DOI: 10.1007/S40273-014-0170-x PMID: 25005924

24. Reed Johnson F, Lancsar E, Marshall D, Kilambi V, Mühlbacher A, Regier DA, et al. Constructing experimental designs for discrete-choice experiments: report of the ISPOR Conjoint Analysis Experimental Design Good Research Practices Task Force. Value Health. 2013;16(1):3-13. DOI: 10.1016/j. jval.2012.08.2223 PMID: 23337210

25. Monthly comparative price levels. Organisation for Economic Co-operation and Development (OECD), 2015. [Accessed 27 Oct 2015]. Available from: http://stats.oecd.org/Index. aspx?Queryld=24057

26. Organisation for Economic Co-operation and Development (OECD). Main economic indicators. OECD; 2013. Available from: http://dx.doi.org/10.1787/mei-v2013-5-en

27. Determann D, Korfage IJ, Lambooij MS, Bliemer M, Richardus $\mathrm{JH}$, Steyerberg EW, et al. Acceptance of vaccinations in pandemic outbreaks: a discrete choice experiment. PLoS One. 2014;9(7):e102505. DOI: 10.1371/journal.pone.0102505 PMID: 25057914

28. International Organization for Standardization (ISO). ISO 26362:2009(en) Access panels in market, opinion and social research. ISO. [Accessed 29 Sep 2015]. Available from: www. iso.org/obp/ui/\#iso:std:iso:26362:ed-1:v1:en

29. International Organization for Standardization (ISO). ISO 20252:2012(en) Market, opinion, and social research International Organization for Standardization (ISO). ISO. [Accessed 29 Sep 2015]. Available from: www.iso.org/obp/ ui/\#iso:std:iso:20252:ed-2:v1:en

30. International Organization for Standardization (ISO). ISO 14001:2015(en) Environmental management systems. ISO. [Accessed 14 Oct 2015]. International Organization for Standardization (ISO), Available from: www.iso.org/obp/ ui/\#iso:std:iso:14001:ed-3:v1:en

31. The ICC/ESOMAR code on Market and Social Research. [Accessed 14 Oct 2015]. Available from: www.esomar.org/ knowledge-and-standards/codes-and-guidelines.php

32. Orme BK. Getting started with Conjoint Analysis: Strategies for Product Design and Pricing Research. Madison, WI: Research Publishers LLC; 2006.

33. Wet medisch-wetenschappeljk onderzoek met mensen. [Medical Research Involving Human Subjects Act]. Dutch. [Accessed 29 Sep 2015]. Available from: http://wetten. overheid.nl/BWBRoo09408

34. Greene WH, Hensher DA. A latent class model for discrete choice analysis: contrasts with mixed logit. Transport Res B-Meth.2003;37(8):681-98. DOI: 10.1016/ S0191-2615(02)00046-2

35. Louviere JH, Hensher DA, Swait JD. Stated choice models: analysis and application. Cambridge: Cambridge University Press; 2000.

36. Kesternich I, Heiss F, McFadden D, Winter J. Suit the action to the word, the word to the action: Hypothetical choices and real decisions in Medicare Part D.J Health Econ. 2013;32(6):1313-24. DOI: 10.1016/j.jhealeco.2012.11.006 PMID: 23317633

37. Linley WG, Hughes DA. Decision-makers' preferences for approving new medicines in Wales: a discretechoice experiment with assessment of external validity. Pharmacoeconomics. 2013;31(4):345-55. DOI: 10.1007/s40273013-0030-0 PMID: 23516033

38. Lancsar E, Louviere J. Conducting discrete choice experiments to inform healthcare decision making: a user's guide.Pharmacoeconomics. 2008;26(8):661-77. DOI: 10.2165/00019053-200826080-00004 PMID: 18620460
39. Bish A, Yardley L, Nicoll A, Michie S. Factors associated with uptake of vaccination against pandemic influenza: a systematic review.Vaccine. 2011;29(38):6472-84. DOI: 10.1016/j. vaccine.2011.06.107 PMID: 21756960

40. Sadique MZ, Devlin N, Edmunds WJ, Parkin D. The effect of perceived risks on the demand for vaccination: results from a discrete choice experiment.PLoS One. 2013;8(2):e54149. DOI: 10.1371/journal.pone.0054149 PMID: 23408936

41. Bults M, Beaujean DJ, de Zwart O, Kok G, van Empelen P, van Steenbergen JE, et al. [Mexican flu: risk perception in the general public, precautionary measures and trust in information provided by the government]. Ned Tijdschr Geneeskd. 2010;154:A1686.PMID: 20482914

42. Zijtregtop EA, Wilschut J, Koelma N, Van Delden J, Stolk RP, Van Steenbergen J, et al. Which factors are important in adults' uptake of a (pre)pandemic influenza vaccine? Vaccine. 2009;28(1):207-27. DOI: 10.1016/j.vaccine.2009.09.099 PMID: 19800997

43. Agüero F, Adell MN, Pérez Giménez A, López Medina MJ, Garcia Continente X. Adoption of preventive measures during and after the 2009 influenza $A\left(\mathrm{H}_{1} \mathrm{~N}_{1}\right)$ virus pandemic peak in Spain.Prev Med. 2011;53(3):203-6. DOI: 10.1016/j. ypmed.2011.06.018 PMID: 21781983

44. Brydak LB, Woźniak Kosek A, Nitsch-Osuch A. Influenza vaccines and vaccinations in Poland - past, present and future.Med Sci Monit. 2012;18(11):RA166-71. DOI: 10.12659/ MSM.883534 PMID: 23111751

45. Börjesson M, Enander A. Perceptions and sociodemographic factors influencing vaccination uptake and precautionary behaviours in response to the $\mathrm{A} / \mathrm{H}_{1} \mathrm{~N}_{1}$ influenza in Sweden.Scand J Public Health. 2014;42(2):215-22. DOI: 10.1177/1403494813510790 PMID: 24259541

46. Seale H, Heywood AE, McLaws ML, Ward KF, Lowbridge CP, Van D, et al. Why do I need it? I am not at risk! Public perceptions towards the pandemic $\left(\mathrm{H}_{1} \mathrm{~N}_{1}\right) 2009$ vaccine. $\mathrm{BMC}$ Infect Dis. 2010;10(1):99. DOI: 10.1186/1471-2334-10-99 PMID: 20403201

47. Barker $\mathrm{Cl}$, Snape MD. Pandemic influenza A H1 $\mathrm{N}_{1}$ vaccines and narcolepsy: vaccine safety surveillance in action.Lancet Infect Dis. 2014;14(3):227-38. DOI: 10.1016/S1473-3099(13)70238-X PMID: 24360892

48. van der Weerd W, Timmermans DR, Beaujean DJ, Oudhoff J, van Steenbergen JE. Monitoring the level of government trust, risk perception and intention of the general public to adopt protective measures during the influenza $A\left(\mathrm{H}_{1} \mathrm{~N}_{1}\right)$ pandemic in The Netherlands.BMC Public Health. 2011;11(1):575. DOI: 10.1186/1471-2458-11-575 PMID: 21771296

49. Mereckiene J, Cotter S, Nicoll A, Lopalco P, Noori T, Weber J, et al. , VENICE project gatekeepers group. Seasonal influenza immunisation in Europe. Overview of recommendations and vaccination coverage for three seasons: pre-pandemic (2008/09), pandemic (2009/10) and post-pandemic (2010/11). Euro Surveill. 2014;19(16):20780. DOI: 10.2807/1560-7917. ES2014.19.16.20780 PMID: 24786262

50. Kardas P, Zasowska A, Dec J, Stachurska M. Reasons for low influenza vaccination coverage: cross-sectional survey in Poland.Croat Med J. 2011;52(2):126-33. DOI: 10.3325/ cmj.2011.52.126 PMID: 21495194

51. Merchant RM, Elmer S, Lurie N. Integrating social media into emergency-preparedness efforts. N Engl J Med. 2011;365(4):289-91. DOI: 10.1056/NEJMp1103591 PMID: 21793742

52. Lin L, Savoia E, Agboola F, Viswanath K. What have we learned about communication inequalities during the $\mathrm{H}_{1} \mathrm{~N}_{1}$ pandemic: a systematic review of the literature.BMC Public Health. 2014;14(1):484. DOI: 10.1186/1471-2458-14-484 PMID: 24884634

53. Nolan JM, Schultz PW, Cialdini RB, Goldstein NJ, Griskevicius V. Normative social influence is underdetected.Pers Soc Psychol Bull. 2008;34(7):913-23. DOI: 10.1177/0146167208316691 PMID: 18550863

54. Schultz PW, Nolan JM, Cialdini RB, Goldstein NJ, Griskevicius V. The constructive, destructive, and reconstructive power of social norms.Psychol Sci. 2007;18(5):429-34. DOI: 10.1111/j.1467-9280.2007.01917.x PMID: 17576283

55. Brien S, Kwong JC, Buckeridge DL. The determinants of 2009 pandemic $A / H_{1} N_{1}$ influenza vaccination: a systematic review.Vaccine. 2012;30(7):1255-64. DOI: 10.1016/j. vaccine.2011.12.089 PMID: 22214889

56. Nguyen T, Henningsen KH, Brehaut JC, Hoe E, Wilson K. Acceptance of a pandemic influenza vaccine: a systematic review of surveys of the general public.Infect Drug Resist. 2011;4:197-207.PMID: 22114512

57. World Health Organization (WHO). Evolution of a pandemic: $\mathrm{A}\left(\mathrm{H}_{1} \mathrm{~N}_{1}\right)$ 2009, April 2009 - August 2010. Geneva: WHO; 2013. Available from: http://apps.who.int/iris/ bitstream/10665/78414/1/9789241503051_eng.pdf?ua=1 
58. Mereckiene J, Cotter S, O'Flanagan D. National seasonal

influenza vaccination survey for 2012-13 influenza season

in EU/EEA (provisional data). Venice III Consortium; 2014.

Available from: http://venice.cineca.org/VENICE_Seasonal

Influenza_2012-13_v10.pdf

\section{License and copyright}

This is an open-access article distributed under the terms of the Creative Commons Attribution (CC BY 4.0) Licence. You may share and adapt the material, but must give appropriate credit to the source, provide a link to the licence, and indicate if changes were made.

This article is copyright of the authors, 2016. 